A Systematic Content Analysis of the Justice Reinvestment Programs Across

Oregon Counties

by

Lorena Ambriz

A thesis submitted in partial fulfillment of the requirements for the degree of

\author{
Master of Science \\ in \\ Criminology and Criminal Justice
}

Thesis Committee:

Mark Leymon, Chair

Brian C. Renauer

Christopher Carey

Portland State University

2020 


\begin{abstract}
High levels of imprisonment and its associated costs have pressured criminologist and policymakers to create and establish new policies intended to reduce incarceration spending and lower the number of individuals under correctional facilities. Justice Reinvestment Initiatives (JRI) have been developed with the basic idea of redirecting the \$54 billion annual incarceration spending toward rebuilding human resources and physical infrastructure of high-risk communities. These initiatives should create local programs that promote successful reentry, reduce recidivism, decrease prison usage, and improve public safety. Oregon passed the Justice Reinvestment Act in 2013, which allowed for all 36 Oregon counties to implement JRI programs to best fit their local needs. The present study explores three questions: 1) do the stated goals of each county fall in line with the seven goals of Oregon's Justice Reinvestment Act, 2) what are the types of programs being developed in each county, and 3) does the Justice Reinvestment Act in Oregon align with the general JRI literature. This analysis is completed using a systematic content analysis (SCA). By categorizing the text of the grant applications through a structured, systematic coding scheme this analysis found the stated goals in Oregon counties are, for the most part, in line with the Justice Reinvestment Act. A total of 95 programs were planned in the 2017-2019 grant applications falling into six categories. Further analysis concludes the Justice Reinvestment Act does not embrace the full literature of justice reinvestment and policy recommendations are made to ensure Oregon is working toward all intended goals.
\end{abstract}




\section{Tables of Contents}

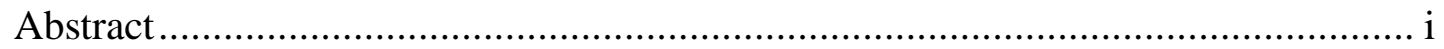

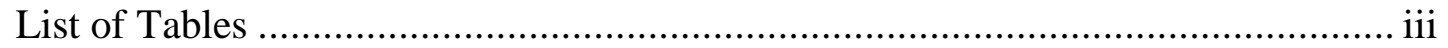

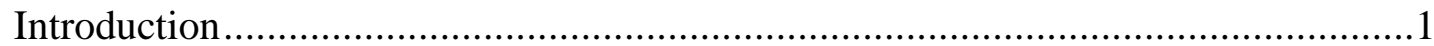

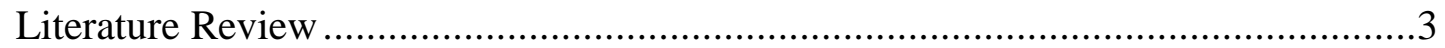

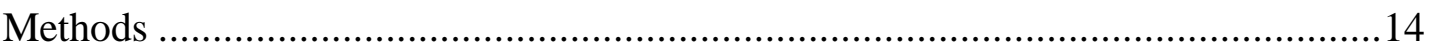

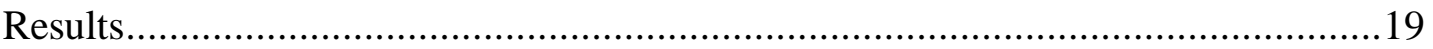

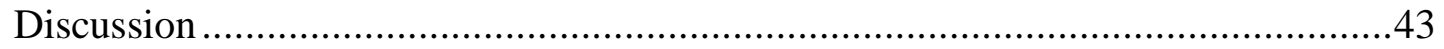

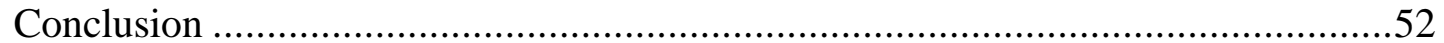

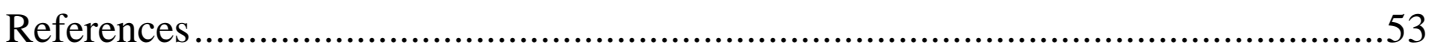




\section{List of Tables}

Table 1 Justice Reinvestment goals compared to House Bill 3194 goals .............................. 12

Table 2 Population, Classification, award amount, and program total of each County .......... 15

Table 3 Community corrections programs in each county by category …............................2 23

Table 4 The type and frequency of specialty courts invested in across Oregon ....................29

Table 5 The type of victim service programs developed across the counties ........................ 31

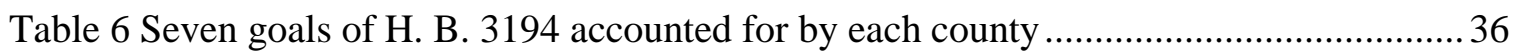

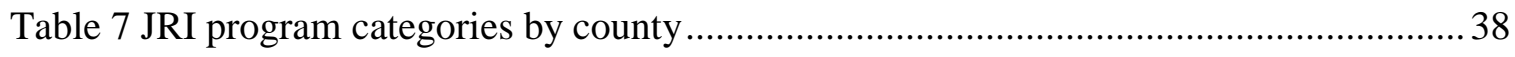

Table 8 Justice reinvestment goals included in Oregon's Justice Reinvestment Act............. 42

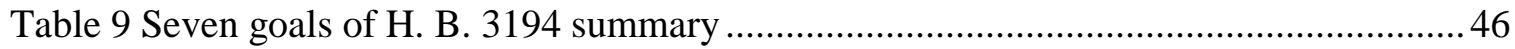




\section{Introduction}

Crimes rates have been decreasing over the past 20 years according to the Uniform Crime Reporting (UCR) data (FBI, n.d.), yet incarceration rates have remained relatively high. There are currently 2.1 million American adults incarcerated in federal, state, and local prisons and jails (Kaeble \& Cowhig, 2018), costing \$54 billion a year (Rivers, 2011). Criminologists and policymakers have called on the use of initiatives like Justice Reinvestment Initiatives (JRI) to decrease incarceration rates and costs, and help offenders successfully integrate back into society, all while improving public safety (Tucker \& Cadora, 2003).

Justice Reinvestment is an evidence-based approach that identifies the drivers of imprisonment and attempts to shift resources to those areas (Rivers, 2011). It aims to reinvest the money saved from using these programs, instead of incarceration, back into the communities most impacted by high incarceration rates. The services provided are supposed to ensure crime is prevented effectively, while increasing public safety (Tucker \& Cadora, 2003). According to Rivers (2011), JRI reaches these goals through four steps: 1) identifying the causes of jails and prison population growth; 2) creating policies which generate savings and increase public safety; 3) quantifying said savings and reinvesting in high-risk communities; and 4) measuring the impact of these initiatives. So far, 35 counites have reformed their criminal justice polices through JRI (PEW, 2018). In certain states, like Oregon, JRI programs vary within the state.

Oregon passed House Bill 3194, also known as the Justice Reinvestment Act, in July of 2013. The goal of this legislation is to invest in public safety infrastructure, 
implement evidence-based community correction programs that are cost-effective and successful in reducing recidivism. It seeks to invest in local law enforcement, community corrections, victim services, and specialty courts. It aims to provide local communities with the resources needed to focus prison resources on violent offenders and hold offenders accountable while boosting public safety. This legislation stresses the need to maintain an effective public safety system by reinvesting cost associated with averted prison growth towards local communities (H.B. 3194, 2013).

This research is not concerned with whether Oregon JRI efforts and programs are effectively reducing recidivism, prison rates, or prison costs. Rather, this research poses two main questions: 1) are counties adhering to the seven goals of House Bill 3194 and 2) what type of programs are being implemented across the 36 counties. The study also includes a sub-analysis of whether the overall JRI efforts in Oregon are in line with core JRI framework themes advanced by the justice reinvestment literature. A systematic content analysis (SCA) approach is taken to answer these questions. The relevance of JRI is first established, along with a detailed description of the national justice reinvestment literature and House Bill 3194. 


\section{Literature Review}

\section{Mass Incarceration}

The rise of mass incarceration in the United States began in the 1970s when the punitive sanction mindset toward criminal activity took popularity. The United States began adapting a punishment-based philosophy, leaving behind the rehabilitative agenda in the 1960s (Clear \& Frost, 2014). The shift towards punitive-based philosophy can be tied to the political discourse of the 1968 presidential election. Both republican candidates, Richard Nixon and George Wallace, ran on a 'law and order' platform, calling for a war on crime. They believed the crime problem in the United states was rooted in rational choice and individual responsibility, a shift from placing the blame on societal issues. This attitude towards crime resulted in a general endorsement of using imprisonment as the primary method to fight crime (Clear \& Frost, 2014). As a result, there was a switch from indeterminate sentencing to determinate sentencing in the mid1970s. Though determinate sentencing was used to reform a variety of sentencing laws, it is generally referred to as sentence set by a judge without the discretion of a parole board (Marvell and Moody, 1996). Determinate sentencing reform led to an increase in length of stay and prison admissions resulting in a $45 \%$ imprisonment increase in 1980 from 1970 (BJS, 1982; BJS, 1984).

Political discourse continued shaping mass incarceration in the 1980s. President Nixon called for a war on drugs during his time in office, declaring illegal drugs "public enemy number one" (Alexander, 2012). However, it was President Reagan’s administration that officially announced the fight on illegal drugs following the crack 
epidemic. This led to the creation of the Sentencing Reform Act of 1984 and the AntiDrug Abuse Act of 1986, which brought severe penalties for drug related offenses (Clear $\&$ Frost, 2014). Through these sentencing reforms, anyone convicted of selling at least five grams of crack cocaine were required to serve a minimum of five years in prison. If caught selling more than 50 grams, a ten-year minimum sentence was required. As a result, the number of people sentenced to a drug-related offence increased from 12,000 in 1980 to 102,000 in 1991 (Clear \& Frost, 2014).

In the 1990s, President Clinton continued this tough-on-crime attitude declaring he would be tougher on crime than any Republican (Alexander, 2012).He shifted the focus towards violent and repeat offenders and addressed them as 'super-predators' referring to 'young and ruthless' delinquents (Clear \& Frost, 2014). It was thought that these teens were the worst set of juvenile offenders of any generation. Violent offences increased 33\% from the mid-80's to the 1990's (Clear \& Frost, 2014) and harsher punishment was seen as the only answer to stop the rise of violence. This political rhetoric gave the public the perception that repeat offenders accounted for a disproportionate share of criminal activity and public sentiment towards harsher sentencing for these offenders grew. During the Clinton administration, mandatory minimums and three-strikes legislation were created. Mandatory sentences required a minimum time to be served of a conviction for certain offenses, meaning judges were not permitted to sentence less than the statutorily mandated minimum (Roberts, 2003). Truthin sentencing was also created during this era. This policy mandated violent offenders to serve $85 \%$ of their sentence by decreasing the discretion of parole boards and 
implementing determinant sentencing practices (Ditto \& Wilson, 1999). Some states also restricted eligibility for parole to ensure full sentence completion. Three-strikes laws were created for violent habitual offenders and varied from state to state, both in terms of sentencing length and number of strikes. Some states would double or triple a sentence, while others would require a life sentence after the final strike. Some states even included drug offense in their three-strikes laws (Clear \& Frost, 2014).

Criminological theories also played a role in these policy creations. Deterrence theory and rational choice theory made their appearance in criminal justice literature during the 70s and 80s (Cullen et al., 2018). Both theories argue that people are rational beings who pursue their own self-interests, capable of weighing the costs and benefits of their actions (Cullen et al., 2018). People will choose to engage in criminal activity if it is advantageous to them. Deterrence theory suggests the only way to prevent crime is through swift, certain, and severe punishment (Bernard et al., 2016). This discourse added to the tough-on-crime movement.

The rise of mass incarceration cannot be fully understood without acknowledging the effects race and poverty had in its development. The 'law and order' platform first emerged in the late 1950s when southern officials publicly opposed the Civil Rights Movement (Alexander, 2012). Civil rights protests were deemed criminal rather than political. The riots that took place after the Martin Luther King Jr. assassination further pushed the narrative of the lawlessness of civil rights. Barry Goldwater's presidential campaign condemned these riots and pushed the fear of 'black crime' which set the foundation for the tough-on-crime movement (Alexander, 2012). Forman (2017) notes 
that Black politicians were also pushing the 'law and order' and tough-on-crime policies, with the goal of protecting Black youth from self-destruction. The war on drugs centered on inner-city neighborhoods, who's increasing unemployment rates left people with limited options. The sale and use of crack cocaine were booming in these neighborhoods and consequently, the target of the war on drugs (Forman, 2017). By 1991, one in four young Black men were in the hands of the criminal justice system (Alexander, 2012).

The Bureau of Justice Statistics estimates 350,000 people were incarcerated in 1970 and by 1980 that number had rose to roughly 520,000 individuals (BJS, 1982; BJS, 1984). At the end of 1990 there were slightly over 1 million incarcerated Americans, reaching almost 2 million by the end of the $20^{\text {th }}$ century (Snell, 1995; West \& Sabol, 2009). Incarceration rates peaked in 2008 with 2.3 million people and have been slightly declining since with a current number of 2.1 million individuals under correctional facilities (Carson, 2018; Zeny, 2018). Given the drastic rise of incarceration since the 1970s, there have been urgent calls for prison reform policies, including justice reinvestment.

\section{Justice Reinvestment Initiative (JRI)}

The realities of American crime and punishment are the driving force for JRI. Tucker and Cadora (2003) argue that the 2.1 million incarcerated Americans is a result of the war on drugs, three-strikes law, mandatory sentencing, and the desertion of the rehabilitative philosophy. Tucker and Cadora (2003), writing in an Open Society Institute paper, present one of the earliest visions of JRI and an arguably broader vision of JRI. They argue imprisonment alone is not enough to guarantee public safety but rather states 
should be investing in services that target education, health, and vocational programs in low-income communities. The focus on low-income communities is vital because if inmates are returning to communities that lack resources, then the chance of successful reentry is compromised.

JRI programs should be used to build an environment that will result in successful transition from prison to community by creating good jobs, accessible healthcare, and affordable education. JRI aims to provide community-level solutions for communitylevel problems. This goes back to the rehabilitative philosophy, focusing on structural issues rather than individual blame. JRI is about placing accountability and responsibility on a local level, where successful reentry is a shared responsibility between the government, the community, and the individual. Local communities need to ask themselves how they can strengthen their neighborhoods to keep their residents out of prison (Tucker \& Cadora, 2003).

Clear (2011) states there are three overarching public opinions which make downsizing incarceration rates feasible. First, as crime rates reduce so does public alarm about crime, creating an opening for new policy ideas. Second, high imprisonment rates demonstrate the necessity to replace policies that sustain mass incarceration with those that will decrease prison rates. Lastly, $68 \%$ of prisoners recidivate within the first three years of being released (Alper et al., 2018), which demonstrates the inability of correctional institutes to properly treat, train, or rehabilitate inmates for life outside of prison. Clear (2011) also argues JRI has broad bipartisan support as it reduces mass incarceration, which appeals to the left, and reduces government costs, which appeals to 
the right. While these public opinions make JRI possible, the main driving force is the fiscal crises many states are facing (Clear, 2011). JRI would redirect the $\$ 54$ billion spent on mass incarceration to rebuild the human resources and physical infrastructure of neighborhoods most impacted by mass incarceration, while also increasing public safety (Tucker \& Cadora, 2003). This is a shift from unproductive spending toward investing in long-term positive changes.

Several states have used the JRI approach to decrease the amount of state funds spent on prisons and to minimize incarceration rates of the state. The Council of State Governments (CSG) Justice Center supported some of the earliest projects in 2004 (Clear, 2011). They began their support in Connecticut, where they estimated saving $\$ 30$ million in imprisonment costs. They used $\$ 13$ million of the savings to reinvest in community-based projects. In 2002, Connecticut had the highest prison growth rate and by 2013 they had the most rapidly decreasing incarceration rate. The CSG Justice Center has worked with 25 states in the past and is currently working with six on JRI projects, including Oregon (CSG, n.d.).

Participating states have created their own version of JRI initiatives with different steps and goals in mind. Taxman et al. (2014) stress the importance that JRI efforts include and increase the number of accessible intervention and treatment programs. They call for effective programing within correctional and community settings. They argue that increased access to these programs can reduce recidivism rates as well as incarceration rates. Welsh-Loveman and Harvell (2018), with the Urban Institute, report the areas in which states with JRI have reinvested their money. Most of these funds have gone 
towards community supervision, treatment, and other community services. The remaining funds have gone towards in-prison programs, law enforcement, victim services, and pretrial reform (Welsh-Loveman \& Harvell, 2018). The Urban Institute has worked with 35 states on JRI projects. As of 2017, they had reinvested \$557 million since 2010. LaVigne et al. (2014) explain there are two types of reinvestments: upfront investment before savings are realized and reinvesting from actual savings. States must first use upfront investments through legislative appropriations to see actual savings. Reinvesting actual savings requires calculation and documentation of actual savings and averted spending.

\section{House Bill 3194}

House Bill 3194, also known as the Justice Reinvestment Act, was introduced into the Oregon legislature in July of 2013. This bill came from the work of the Commission of Public Safety and its collaboration with the Justice Reinvestment Initiative (JRI). The commission was a bipartisan collaboration lead by the Department of Corrections, Oregon Supreme Court, and the state legislature. In 2012, the Oregon Governor tasked the commission with developing evidence-based policies that would decrease the rate and cost of corrections while improving public safety (LaVigne et al., 2014). After identifying the drivers that lead to Oregon's 50\% prison increase from 2000 to 2010 , several policies were created, including removing mandatory minimums for repeat drug offenders and reducing sentences for marijuana offenses, driving while suspended, and other non-violent offenses; strengthening reentry programming by expanding transitional leave, implementing earned discharge, and requiring the use of risk-needs evaluations; 
and by requiring reports on progress and financial spending for community supervision, rehabilitation research, and evidence-based programing to the Oregon Criminal Justice Commission (CJC) (House Bill 3194, 2013; LaVigne et al., 2014).

The goals of this legislation were to invest in public safety infrastructure by implementing evidence-based community correction programs that are cost-effective and successful in reducing recidivism. Invest in local law enforcement, community corrections, victim services, and specialty courts. Provide local communities with the resources needed to focus prison resources on violent offenders and hold offenders accountable while protecting public safety. This legislation aims to maintain an effective public safety system by reinvesting cost associated with averted prison growth towards local communities (H.B. 3194, 2013). Through the governor's budget and legislative appropriations, Oregon initially invested $\$ 58$ million of projected prison cost savings to support local programs (LaVigne et al., 2014). As of 2016, Oregon has reinvested $\$ 98$ million in upfront savings and subsequent reinvestment from savings and averted costs (Urban Institute, 2017). The bill also created the Justice Reinvestment Grant Program to distribute the savings from averted prison growth among the 36 Oregon counties. The CJC webpage states the target of this program is to "financially support Oregon counties to plan, implement, or expand initiatives that reduce recidivism, reduce prison population, increase public safety, and hold offenders accountable," (CJC, n.d.a). The grant program requires counties to use three percent of their funds for research and ten percent for victim services, resulting in counties using $87 \%$ of their funds to develop 
local programs. Every two years counties apply for the grant by describing how they plan to use their JRI funds (CJC, n.d.a).

Seven specific goals can be obtained from the House Bill 3194 text: 1) focus prison resources on violent offenders, 2) invest in evidence-based community corrections, 3) invest in local law enforcement, 4) invest in specialty courts, 5) invest in victim services, 6) hold offenders accountable, and 7) increase public safety. House Bill 3194 allows each county to implement JRI programs that best support the local needs of the community, so long as they fall in line with the goals of the act.

The main focus of this research is whether the stated goals of each county are adhering to the seven objectives of the Justice Reinvestment Act. Second, this study will examine the type of programs developed across each county. The last thing this research will examine is if the Justice Reinvestment Act falls in line with the overall JRI literature.

The 2017-2019 grant applications are used to assess the first and second research questions. These applications only demonstrate the intention of implementing programs and the intent of complying with the seven goals of House Bill 3194. The applications alone cannot guarantee counties are actually implementing programs or meeting the seven goals. Measuring actual implementation would have been ideal for this study, but the available data did not allow for such analysis. Nonetheless, there is still a benefit in studying intent. Studying intent visualizes the problems of each county and the approach they plan to take. A similar issue can be resolved through different approaches, thus the stated intent to address an issue gives a better understanding of the resources, and skillset, and political preferences of each county. 
The second research question examines differences in the type of programs each county planned to implement. This analysis will help establish any major themes across counties, especially considering the difference between urban and rural counties. The amount of funds each county receives will likely have an impact on the type of programs they are able to develop. This analysis will allow inferences to be made about the programs in Oregon.

The sub-analysis of this study asks if the goals of House Bill 3194 fall in line with the JRI literature. As seen in Table 1, both generally share the same overall goals and differ in only a few ways. This study will examine if the goals that are not stated in Oregon are vital to the JRI literature. This study will see how Oregon intends to reach

\section{Table 1}

Justice Reinvestment goals compared to House Bill 3194 goals

\begin{tabular}{|c|c|}
\hline Goals of General JRI & House Bill 3194 goals \\
\hline Decrease prison use & Decrease prison use \\
\hline Reduce recidivism & Reduce recidivism \\
\hline Reduce prison costs & Reduce prison costs \\
\hline Increase public safety & $\begin{array}{l}\text { Hold offenders accountable and increase public } \\
\text { safety }\end{array}$ \\
\hline Assess the measures & Assess the measures \\
\hline Reinvest actual savings & Reinvest actual savings \\
\hline $\begin{array}{l}\text { Reinvest into the physical infrastructure } \\
\text { of high-risk communities }\end{array}$ & Reinvest into local public safety infrastructure \\
\hline \multirow[t]{2}{*}{ Invest in proactive measures } & $\begin{array}{l}\text { Invest in law enforcement, community } \\
\text { corrections, and specialty courts }\end{array}$ \\
\hline & Focus prison resources on violent offenders \\
\hline
\end{tabular}


their goals and how the intended efforts of the counties aid in their plans for JRI implementation. The implications of these differences will be discussed.

These three questions will help establish if there is fidelity within JRI in Oregon. This research aims to demonstrate if the practices fall in line with the bill and if the bill falls in line with the overall JRI literature. Consequently, three questions are posed: 1) are counties adhering to the eight goals of House Bill 3194, 2) what are the type of programs being implemented across the 36 counties, and 3) whether the overall JRI efforts in Oregon are in line with the justice reinvestment literature. 


\section{Methods}

\section{Data Sample}

Data for this analysis was collected from the Oregon Criminal Justice

Commission, specifically from the Justice Reinvestment Grant Program. The program manager supplied the 2017-2019 grant applications for all 36 counties. The applications include a short narrative of each program and their expected cost. There is specific language asking who they are targeting, research on evidence-based practices, and how they plan to measure the effectiveness of each program. The applications ask counties to provide an explanation on how they plan to reduce recidivism, lower prison use for driving, drug, and property offenses, hold offenders accountable, and increase public safety. Information on how much of the grant fund each count received for the 2017-2019 biennial is also provided. While application exist for the 2013-2015 and the 2015-2017 grant cycle, this analysis only examined the most recent grant applications.

To get a better understanding of the 36 Oregon Counties, Table 2 list counties' population size, the classification of the county (i.e. urban vs rural), the amount of grant funds they received for the 2017-2019 biennial, and the number of programs they planned to implement. The placement of urban or rural comes from the United States Census Bureau. They classify counties with less than 50,000 people as rural and those with 50,000 or more are considered urban counties (U.S. Census Bureau, 2019). All tables in this study will be organized from the highest populated county to the least populated. 
Table 2

Population, classification, award amount, and program total of each county

\begin{tabular}{|c|c|c|c|c|}
\hline & Population $^{1}$ & Classification $^{2}$ & Award $(\$)^{3}$ & JRI programs \\
\hline Multnomah & 811,880 & Urban & $7,888,646$ & 1 \\
\hline Washington & 597,695 & Urban & $3,746,921$ & 2 \\
\hline Clackamas & 416,075 & Urban & $2,411,582$ & 3 \\
\hline Lane & 379,611 & Urban & $3,707,060$ & 3 \\
\hline Marion & 346,868 & Urban & $3,754,893$ & 8 \\
\hline Jackson & 219,564 & Urban & $2,240,180$ & 4 \\
\hline Deschutes & 191,996 & Urban & $1,741,920$ & 1 \\
\hline Linn & 127,335 & Urban & $1,654,226$ & 2 \\
\hline Douglas & 110,285 & Urban & $1,642,267$ & 4 \\
\hline Yamhill & 107,002 & Urban & 944,702 & 2 \\
\hline Benton & 92,101 & Urban & 514,205 & 3 \\
\hline Josephine & 87,393 & Urban & $1,191,840$ & 5 \\
\hline Polk & 85,234 & Urban & 597,913 & 4 \\
\hline Umatilla & 77,516 & Urban & 916,800 & 3 \\
\hline Klamath & 67,653 & Urban & $1,227,714$ & 1 \\
\hline Coos & 64,389 & Urban & 789,245 & 1 \\
\hline Columbia & 52,377 & Urban & 554,066 & 1 \\
\hline Lincoln & 49,388 & Rural & 581,969 & 1 \\
\hline Clatsop & 39,674 & Rural & 486,302 & 1 \\
\hline Malheur & 30,725 & Rural & 290,984 & 1 \\
\hline Tillamook & 26,787 & Rural & 298,956 & 5 \\
\hline Wasco & 26,505 & Rural & 458,400 & 3 \\
\hline Union & 26,461 & Rural & 310,915 & 3 \\
\hline Jefferson & 24,194 & Rural & 346,789 & 4 \\
\hline Crook & 23,867 & Rural & 298,956 & 4 \\
\hline Hood River & 23,428 & Rural & 155,457 & 4 \\
\hline Curry & 22,813 & Rural & 215,249 & 1 \\
\hline Baker & 16,006 & Rural & 223,221 & 2 \\
\hline Morrow & 11,372 & Rural & 139,513 & 1 \\
\hline Lake & 7,879 & Rural & 171,402 & 1 \\
\hline Harney & 7,329 & Rural & 127,555 & 2 \\
\hline Grant & 7,176 & Rural & 100,000 & 3 \\
\hline Wallowa & 7,081 & Rural & 100,000 & 5 \\
\hline Gilliam & 1,890 & Rural & 100,000 & 1 \\
\hline Sherman & 1,708 & Rural & 100,000 & 4 \\
\hline Wheeler & 1,366 & Rural & 100,000 & 1 \\
\hline
\end{tabular}

${ }^{I}$ U. S. Census Bureau (n.d.)

${ }^{2}$ U. S. Census Bureau. (2019)

${ }^{3}$ CJC (n.d.b) 


\section{Analytical Technique}

A systematic content analysis (SCA) of the 2017-2019 grant applications was used to analyze this data. Drisko and Maschi (2015) define content analysis as a research technique that allows researchers to make valid inferences from large texts. This strategy categorizes parts of text through a structured, systematic coding scheme. Inferences can then be made about the message itself, the authors or receivers of the message, and even the impact of the message. This analysis allows for replication by providing clear specifications of the coding and procedures. According to Salehijam (2018), SCA is a frequently utilized tactic by social scientists and researchers "to analyze interview transcripts, literature, and field notes amongst other sources" (p. 35). SCA can produce both qualitative and quantitative results by enabling the researcher to condense large amount of text into fewer content categories (Salehijam, 2018). The 2017-2019 JRI grant applications were on average 96 pages in length. The use of a software tool, ATLAS.ti, made this analysis more productive. ATLAS.ti provides the ability to create consistent, valid, and adequate codes as described by Quesada (2010). Quesada found the use of this software tool to increase productivity in data analysis.

Before running the 36 applications through ATLAS.ti, the applications were first manually analyzed to understand what kind of codes could be created with the provided documents. Since all the programs have very specific names, categorizing the programs had to be done by hand. For example, Malheur county named their diversion program MC 3194 Supervision. This specific name could not be grouped with other diversion programs using ATLAS.ti. Categorizing the type of community corrections programs 
were done manually for the same reason listed above. Quantifying the number of programs each county had applied for also required manual labor. This approach was used to answer the second research question, which examines the differences in the types of JRI programs across Oregon.

All 36 applications were uploaded to ATLAS.ti with the name of the county and the number depending on the population rank. Multnomah county was labled number one since it has the highest population count and Wheeler County was numbered 36 as it has the least number of people. Seven codes were developed using ATLAS.ti: Law Enforcement, Public Safety, Not Evidence-Based, Offender Accountability, Specialty Courts, Victim Services, and Violent Offenders. Developing the code for Law Enforcement required going to the budget section of every application and focusing on the personnel, training, and equipment sections. The personnel section listed the type of personnel (i.e. officers, managers, legal assistants, etc.), whether they were full-time or part-time hires, and the salary amount. Counites that listed parole officers, probation officers, retrial officers, or deputy sheriffs were added into the Law Enforcement code, as well as counties that listed training and equipment in their budget. The Not EvidenceBased code was made by going to the program description of each program and reading the section that asked how the program was evidence-based. Programs that did not account for how they were based in evidence or did not give an adequate explanation were added to this code.

Public Safety, Offender Accountability, Specialty Courts, Victim Services, and Violent Offenders codes were analyzed using the same strategy. An auto-code was run 
looking for the exact word(s) in the applications. The software highlighted the sentence in which the word(s) appeared. Sentences that were relevant to the topic were added to that specific code and those that were not useful were left out. Once all the codes were created, a report was produced for each code and later used to write up the results of the main research question and answer if the intended goals of each county were in line with the seven goals of House Bill 3194. 


\section{Results}

The first research question asks if the 36 Oregon counties are aiming for the seven goals of House Bill 3194. The results of this SCA are discussed in the order of the goals, which are 1) focus prison resources on violent offenders, 2) invest in evidence-based community corrections, 3 ) invest in local law enforcement, 4) invest in specialty courts, 5) invest in victim services, 6) hold offenders accountable, and 7) increase public safety.

\section{1) Focus prison resources on violent offenders}

The analysis revealed only seven of the 36 counites (19\%) included specific language about excluding violent offenders from their JRI programs. Multnomah county aimed to exclude sex crimes, domestic violence, offenses against children, and the majority of violent offenses from their Multnomah County Justice Reinvestment Program (MCJRP) eligibility. High-risk property offenders in Lane county were said to be placed under community supervision while violent offenders would be sent to prison. Benton county's drug treatment program claims to not process offenders with possession of a substantial quantity of drugs, delivery or manufacturing of drugs, other commercial drug offenses, or certain violent offenses. The aim of Clatsop county's pretrial release program is to free up jail beds and reserve them for violent offenders. They state that female offenders would be most eligible for this program as they are less likely to be convicted of violent offenses.

The drug treatment court and prison diversion program in Marion County are tailored towards non-violent offenders. Specifically, their target population for the drug treatment court are non-violent misdemeanor and felony drug offenders who possess 
medium or high criminogenic risk factors. Yamhill County gives the following account for how their SMART evidence-based sentencing program focuses prison resources on violent offenders,

Yamhill County's SMART Evidence-Based Sentencing Program has reduced the local state prison population by identifying prison-bound non-violent offenders who can be deferred from prison and safely managed in the community under supervision. (Yamhill County application).

The JRI program in Malheur county is reserved for offenders who are short-term transitional leave inmates, on downward departure probation, have substance related offenses, have property offenses, or are non-violent mentally ill offenders with substance or property related offenses.

These findings cannot definitively conclude that the remainder of the counties are allowing some proportion of violent offenders to be part of their JRI initiatives. Hence, it is unclear the types of offenders being impacted by almost all the JRI programs in the state and whether the goal is being met or not. These results demonstrate there is a lack of language regarding inclusion or exclusion of violent offenses in the grant applications. This could be remedied by asking counties to specifically clarify the offense types eligible, targeted, or impacted by their initiatives. It is also important to note that the bill itself takes action on this front. The Justice Reinvestment Act modified sentences for felony marijuana offenses, property offenses, and for driving on a suspended license. It modified presumptive sentences for certain identity theft or robbery offenses and eliminated mandatory minimum sentences for certain drug offenses. This bill aimed to direct prison resources towards violent offenders by placing property, drug, and driving 
offenders under community supervision and away from prison. This allows for JRI funds to be used towards supervising non-violent offenders in the community.

\section{2) Invest in evidence-based community corrections}

There are approximately 29,000 individuals under community supervision in the state of Oregon (DOC, 2018). Oregon has upwards of 15,000 offenders under prison or jail facilities with 10,000 convicted of violent crimes (DOC, 2018). The aim to reserve prison resources for violent offenders gives the possibility of 5,000 more inmates being placed under community corrections in Oregon, requiring counties to invest in community correction services. The Justice Reinvestment Act explicitly states the need for these community correction programs to be evidence-based, cost-effective, and successful in reducing recidivism. Twenty-six out of the 36 counties (72\%) planned to implement community correction services including reentry programs, transitional housing, diversion programs, day reporting centers, work crew programs, and other general community correction services.

Reentry programs are designed to help inmates successfully integrate back into the community. These programs provide an array of services including mentoring, mental health treatment, substance abuse treatment, housing, vocational training, educational opportunities, parenting classes, cognitive treatment, transportation, among other basic resources depending on the needs of each individual (Gill \& Wilson, 2017). Transitional housing programs are community based residential facilities and are similar to reentry programs. The goals of both these programs are to reduce recidivism and to aid in successful reintegration through treatment, support, and assistance (Garland et al., 
2017). House Bill 3194 modified the Oregon law to increase the maximum period of short-term transitional leave and required the Department of Corrections to assist inmates in applying for transitional leave programs.

Diversion programs are a type of sentencing where adults are referred to community-based treatment programs to reduce prison or jail overcrowding. They attempt to fix the underlying behavior problem that led to the criminal act through supervision and treatment (Wong et al., 2019). Day reporting centers share similar characteristics as diversion programs as alternative sanctions to prison. Both programs require regular check-ins and provide treatment services as appropriate (Craddock, 2004). Work crew programs are alternative sanctions where offenders are required to work for a certain number of hours on community service projects. Many argue this is a form of restorative justice in which offenders make up for their anti-social behavior through community involvement (Wood, 2012). Given the difference in structure of reentry programs and transitional housing, the assumption can be made that diversion programs, day reporting centers, and work crew programs cost less. However, being a cheaper option is not to say these services are cost-effective.

Table 3 displays the kind and quantity of community correction programs said to be operative in the JRI initiatives across Oregon. Thirteen counties invested in transitional housing and twelve funded reentry programs. Work crew programs were planned in five counties, three counties aimed to use diversion programs, and day reporting centers were reported in only two counites. General community correction 
Table 3

Community corrections programs in each county by category

\begin{tabular}{|c|c|c|c|c|c|c|}
\hline & Reentry & Transitional & Day report & Work crew & General & Diversion \\
\hline Multnomah & & & & & $\checkmark$ & \\
\hline Washington & $\sqrt{ }$ & & & & & \\
\hline Clackamas & & $\sqrt{ }$ & & & & \\
\hline Lane & $\sqrt{ }$ & & & & & $\sqrt{ }$ \\
\hline Marion & $\sqrt{ }$ & $\sqrt{ }$ & & & & $\sqrt{ }$ \\
\hline Jackson & $\sqrt{ }$ & & $\sqrt{ }$ & & & \\
\hline \multicolumn{7}{|l|}{ Deschutes } \\
\hline Linn & $\sqrt{ }$ & & & & & \\
\hline \multicolumn{7}{|l|}{ Douglas } \\
\hline \multicolumn{7}{|l|}{ Yamhill } \\
\hline Benton & & $\sqrt{ }$ & & & $\sqrt{ }$ & \\
\hline Josephine & & $\checkmark$ & & & & \\
\hline Polk & & $\checkmark$ & & & & \\
\hline Umatilla & & & $\checkmark$ & & & \\
\hline \multicolumn{7}{|l|}{ Klamath } \\
\hline Coos & & & & & $\checkmark$ & \\
\hline \multicolumn{7}{|l|}{ Columbia } \\
\hline Lincoln & $\checkmark$ & & & & & \\
\hline \multicolumn{7}{|l|}{ Clatsop } \\
\hline Malheur & & $\sqrt{ }$ & & & & $\sqrt{ }$ \\
\hline Tillamook & $\checkmark$ & & & $\checkmark$ & $\checkmark$ & \\
\hline Wasco & $\checkmark$ & $\checkmark$ & & & & \\
\hline Union & & $\checkmark$ & & $\checkmark$ & & \\
\hline Jefferson & $\checkmark$ & & & & & \\
\hline Crook & & $\sqrt{ }$ & & & $\checkmark$ & \\
\hline Hood River & $\checkmark$ & $\checkmark$ & & & & \\
\hline Curry & & $\checkmark$ & & & & \\
\hline Baker & & & & $\checkmark$ & & \\
\hline \multicolumn{7}{|l|}{ Morrow } \\
\hline \multicolumn{7}{|l|}{ Lake } \\
\hline Harney & $\checkmark$ & & & & & \\
\hline Grant & & $\checkmark$ & & & & \\
\hline Wallowa & & $\checkmark$ & & $\sqrt{ }$ & & \\
\hline \multicolumn{7}{|l|}{ Gilliam } \\
\hline Sherman & $\checkmark$ & & & $\checkmark$ & & \\
\hline Wheeler & & & & & & \\
\hline
\end{tabular}


programs were developed in five counties and have similar aspects of the other

community correction programs including treatment, support, and supervision. Of the counties that hoped to implement community correction programs, half included more than one program as seen in Table 3.

\section{Invest in evidence-based community corrections}

The 26 counties that sought to invest in community correction programs, made sure they were investing in evidence-based community corrections. The JRI grant application for Oregon required every county to explain how each of their programs were based in evidence. All proposed community correction programs were alleged to be based in evidence. Some counties provided more detailed explanations of their evidencebased practiced than others. For example, Baker county justified their work crew program by stating "numerous studies that have shown community service is one of the most impactful sanctions in reducing recidivism," but provided no further explanation. On the other hand, Lane county gave the following account for their reentry program,

All partners in this program apply the principles of Risk, Needs, and Responsivity. They also follow the "Fundamental Principles of Evidence-Based Correctional Practice" as described below...staff administer the LS/CMI prior to release from prison and immediately after clients are admitted to the program... programs utilize Motivational Interviewing (MI). MI is included on SAMHSA's National Registry of Evidence Based Programs and Practices (NREPP)...tailored case plan[s] for each client which addresses the top criminogenic risks/need factors [are developed]...Sponsors and Emergence both use Moral Reconation Therapy (MRT) which targets criminogenic predictors of crime and recidivism...POs also utilize the SAFE curriculum as cognitive behavioral interventions, skill building, and homework to contribute to the required dosage proven to reduce risk and overall recidivism. (Lane county application). 
Benton county explained the evidence-based component of their community correction

program as follows,

Benton County utilizes core principles of EBP to implement and sustain researchbased supervision and case management practices which best addresses offender needs. We continue to build the evidence-based skill-set of our staff and focus on EBP strategies, including the use of validated risk assessments, Case Plans, Carey Guides, Change Contracts (action plans)....Benton County Community Corrections addresses all criminogenic risk factors through a validated risk assessment tool, and having access to vital services, sanctions, and programs designed to address risk factors enhances our ability to contribute to offender success...The programming is highly interactive and engages participants in curriculum that assists them in examining their thoughts, behavior and core values. These programs are available to all supervised offenders. Evidence-based cognitive behavioral programs include Thinking for a Change and Anne Fields Motivational Enhancement Therapy (MET).

Of the programs that were not community corrections related, four did not describe their evidence-based practices. One of the programs came from Harney county, which planned to implement security cameras in their transitional housing unit. They did not address how their implementation of cameras were evidence based. This is not a program but merely an equipment needed for their transitional housing services. Wallowa county wanted to develop an alcohol, drug, and mental health program. From their description of the program, the aim was to work with a local clinic to administer drug tests on their clients. They did not address how this program is evidence-based.

Two of the four programs described by Sherman County were not evidencebased. The Sherman County Community Outreach aims to provide an array of training to offenders on parole or probation. They do not address how these programs are based in evidence, but rather give a description of what they believe will be helpful. The other 
program aimed to hire a work crew supervisor, which would supervise their clients doing community services. Much like Harney county, this is not necessarily a program, but a position for a program. They also fail to state the connection to evidence-based practices or success of this position, but rather point to the use of this position in other states. While these programs could be argued to be evidence-based, these three counties do not present a clear argument.

\section{3) Invest in local law enforcement}

If counties are expanding their community correction services, then each agency will require additional resources to adequately serve their clients. Twenty-six of the 36 counties intended to invest in local law enforcement in the form of hiring addition fulltime and part-time parole and probation officers, pretrial officers, and deputies, as well as investing in officer training and equipment. Over half of the 26 counties supported more than one type of investment. Of the 15 counties that wanted to hire one or more full time probation or parole officers, ten were from urban counties. Urban counties received more JRI funds likely because of the higher number of offenders compared to rural counties. Most rural counties likely did not have the justification or the funds to hire a full-time officer.

Hiring more officers was generally done with the intention to aid in their community corrections programs. Tillamook county explained their parole and probation officer program as follows,

The grant funded Parole and Probation Officer Program is a full-time Parole and Probation Officer position. The officer will carry a general case load with felonies 
and misdemeanors that has a focus on drug and driving related crime. The officer will perform duties as defined in ORS 181.610(13), 137.620 and 137.630... areas of training are required for this grant funded parole and probation officer position. Therefore, the officer is required to attend the academy and obtain Parole and Probation Basic Certification...It is important that the officers are current and up to date with evidence based practices, risk assessment tools, specialty training for specific caseloads (sex offenders and domestic violence) and are able to gain their required hours of training in specific areas; firearms and use of force, ethics, CPR and first aid, and leadership (when applicable). (Tillamook county application).

Morrow county gave the following explanation for why they needed an additional parole and probation officer,

The Officer Position that the Justice Reinvestment Grant is funding has reduced the current amount of offenders on each caseload. Our caseloads were [approximately] 55 before we hired the new position. The caseloads per officer are now [approximately] 36. It has enhanced public safety by allowing more offender contacts in the community and in the office. It has allowed more work crew sanctions instead of jail sanctions (work crew also helps teach offenders good work ethics). (Morrow county application).

Six counites planned to hire one or more part-time officers, half from rural counties and half from urban counties. Urban counties also had the goal of hiring pretrial officers, full time deputies, and part time deputies. Only one rural county, Clatsop county, arranged to hire one pretrial officer for their only JRI program, which is a pretrial service program. Officer training was intended in eight different counties, six of which are rural. Three rural counties also hoped to get more equipment for their agencies. It is likely urban counties already had the equipment necessary for their everyday workday. Even though rural counties were not as likely to hire additional officers, they were more likely to invest in officer training and equipment, which directly benefits the agency. 


\section{4) Invest in specialty courts}

In the 1980s, specialty courts were developed to address the underlying issues that impact criminal behavior. The objective of a specialty court is to divert an offender away from prison or jail and provide rehabilitative services to reduce odds of recidivism (Wood et al., 2018). These specialized courts focus on specific issues such as addiction, family, veteran's issues, among others. Since specialty courts were created with the purpose of reducing recidivism, investing in them aligns with the Justice Reinvestments Act. The two most mentioned courts in the 2017-2019 grant applications were drug courts and mental health courts. Drug courts were formed as a response to the soaring number of drug and alcohol related offenses. They provide effective treatment and appropriate sanctions through a collaboration between the courts and the community (Morgan et al., 2016). Mental health courts operate in the same manner with the focus being mental health treatment rather than drug or alcohol addiction (Frailing, 2010).

While only five counites plotted to develop specific specialty court programs (see Table 7), 19 of the 36 counties (53\%) intended to invest in preexisting specialty courts. Drug courts were set to receive funds from 14 counites, six counties wanted to help fund mental health courts, three aimed to invest in veteran treatment courts, and two targeted family courts. Multnomah county and Polk county vaguely stated their JRI funds were helping fund specialty courts, but they did not specific the type of court. Eleven urban counties stated they wanted to invest in specialty courts compared to eight rural counties. Table 4 displays the frequency and the type of courts mentioned in the grant applications. 


\section{Table 4}

The type and frequency of specialty courts invested in across Oregon

\begin{tabular}{ll}
\hline Specialty Court & Frequency \\
\hline Adult Drug Court & 14 \\
Mental Health Court & 6 \\
Veterans Treatment Court & 3 \\
Specialty Court: not specified & 2 \\
Family Court & 2 \\
Family Dependency Court & 1 \\
Reentry Court & 1 \\
Community Diversion Courts & 1 \\
Community Court & 1 \\
Hybrid Treatment Court & 1 \\
Fostering Attachment treatment Court & 1 \\
Behavioral Intervention Court & 1 \\
Counites not invested & 17 \\
\hline
\end{tabular}

The following courts were only referred to by one county: family dependency court, reentry court, community diversion courts, community court, hybrid treatment court, fostering attachment treatment court, and behavioral intervention court.

\section{5) Invest in victim services}

The JRI grant requires ten percent of the funds allocated to each county to go towards victim services, consequently $100 \%$ of counites have enacted victim service programs. Three categories were extracted from all victim services programs implemented in Oregon: domestic violence and sexual assault, child abuse and neglect, and general victim services. Multnomah county and Curry county were the only counites 
to allege the implementation of all three services. Sixteen counties focused on both domestic violence and sexual assault and child abuse and neglect programs. The remaining counties only aimed to develop one of the three services in their communities. Table 5 displays the type of victim services hoped to be adopted by each county. Twelve counties solely focused on domestic violence and sexual assault services, two counties only wanted child abuse and neglect services, and four all rural counties aimed to fund only general victim services. Overall, 30 counties (83\%) wanted to fund programs specifically tailored towards survivors of domestic violence and sexual assault, 20 counties (56\%) wanted child abuse and neglect services, and six counties (17\%) claimed to invest in general victim services.

General victim services are services not focused on specific groups but are rather focused on helping all victims through processing trauma including mental health counseling and life enrichment workshops. Wheeler county was the only county to allocate more than the required percentage towards victim services, with $20 \%$ of their JRI funds going towards victim services.

\section{6) Hold offenders accountable}

The push towards less prison use may give the public the impression that offenders are being let off for their crimes. The Justice Reinvestment Act makes it a point that holding offenders accountable for their actions is required of every county. In the JRI grant application, counties are asked how their programs are designed to hold offenders 
Table 5

The type of victim service programs developed across the counties

\begin{tabular}{|c|c|c|c|}
\hline & $\begin{array}{c}\text { Domestic violence \& sexual } \\
\text { assault }\end{array}$ & Child abuse and neglect & $\begin{array}{c}\text { General victim } \\
\text { services }\end{array}$ \\
\hline Multnomah & $\checkmark$ & $\checkmark$ & $\checkmark$ \\
\hline Washington & $\checkmark$ & $\checkmark$ & \\
\hline Clackamas & $\checkmark$ & $\checkmark$ & \\
\hline Lane & $\checkmark$ & $\checkmark$ & \\
\hline Marion & $\checkmark$ & $\checkmark$ & \\
\hline Jackson & $\checkmark$ & $\checkmark$ & \\
\hline Deschutes & $\checkmark$ & $\checkmark$ & \\
\hline Linn & $\checkmark$ & $\checkmark$ & \\
\hline Douglas & $\checkmark$ & $\checkmark$ & \\
\hline Yamhill & $\checkmark$ & $\checkmark$ & \\
\hline Benton & $\checkmark$ & $\checkmark$ & \\
\hline Josephine & $\checkmark$ & & \\
\hline Polk & $\checkmark$ & $\checkmark$ & \\
\hline Umatilla & $\checkmark$ & & \\
\hline Klamath & $\checkmark$ & & \\
\hline Coos & $\checkmark$ & $\checkmark$ & \\
\hline Columbia & $\checkmark$ & $\checkmark$ & \\
\hline Lincoln & $\checkmark$ & $\checkmark$ & \\
\hline Clatsop & $\checkmark$ & $\checkmark$ & \\
\hline Malheur & $\checkmark$ & & \\
\hline Tillamook & $\checkmark$ & & \\
\hline Wasco & $\checkmark$ & & \\
\hline Union & $\checkmark$ & $\checkmark$ & \\
\hline Jefferson & $\checkmark$ & & \\
\hline Crook & & $\checkmark$ & \\
\hline Hood River & & $\checkmark$ & \\
\hline Curry & $\checkmark$ & $\checkmark$ & $\checkmark$ \\
\hline Baker & $\checkmark$ & & \\
\hline Morrow & $\checkmark$ & & \\
\hline Lake & $\checkmark$ & & \\
\hline Harney & $\checkmark$ & & \\
\hline Grant & & & $\checkmark$ \\
\hline Wallowa & & & $\checkmark$ \\
\hline Gilliam & & & $\checkmark$ \\
\hline Sherman & $\checkmark$ & & \\
\hline Wheeler & & & $\checkmark$ \\
\hline
\end{tabular}


liable. This goal is less concrete, giving counties the ability to interpret this with more liberty than the first five goals.

Every county, with the exception of Gilliam county, detailed how their JRI programs promote offender accountability. The main methods of promoting accountability were through increased supervision and finding alternative sanctions. Supervision strategies varied between counties and between offenders. With the use of the risk-needs assessment, programs were able to identify the most appropriate form for community supervision for each offender. Generally, risk-needs assessments include identifying the offender's traits, past behavior, and criminogenic needs to categorize their likelihood of recidivism. This information is used to provide the proper rehabilitative intervention and the suitable level and form of supervision (Miller \& Maloney, 2013). Counties identified pretrial release supervision, electronic court date reminders, day reporting centers, frequent contact with clients, ensuring restitution payments were being made, electronic monitoring, alcohol monitoring, and random drug tests as forms of supervision that hold offenders liable for their criminal behavior.

Collaborative tactics with treatment service providers and parole and probation officers were also used to ensure accountability. Some counties invested in additional jail beds in order to hold offenders accountable under jail supervision. Counties made the distinction between long-term and short-term strategies in promoting accountability. Short-term strategies included swift and certain punishment, while long-term strategies included treatment services focused on behavior change. For example, Crook county 
stated their Batterer's Intervention Program is a long-term strategy given the specific behavior change they aimed to attain.

Some counties had unique approaches to offender accountability. Multnomah county wanted to partner with the victims allowing them to report any concerns or issues. Klamath county gave the following account,

KCCC has assigned an Accountability Team (A-Team) to increase accountability. Each day a team of Parole and Probation Officers are assigned to fieldwork. The team receives notice of offenders who do not attend treatment, community service, or other services as directed. Once the notices are received, the A- Team immediately responds by going into the field to locate the offender. The A-Team can provide a ride to the service; impose an intervention or a sanction. (Klamath county application).

Klamath county is an urban county with a detailed plan on how they plan to hold offenders accountable. Wheeler county, with a population of less than 2,000 people, believed social stigma through community service was enough for offenders to feel accountable. They state,

Community Service as a form of sentencing allows for the public to observe the end results of someone who is being held accountable for their transgressions against the criminal justice system. This public awareness may act to discourage others from offending...This has an overall deterrent effect on whether the offender feels that they can commit new crimes. (Klamath county application).

This approach in holding offenders accountable is simple compared to the plan of Klamath county. Gilliam county did not spell out any specific approach for offender accountability. They mention having a goal of holding offenders liable, but they do not mention any steps they have taken. 


\section{7) Increase public safety}

Much like the goal of offender accountability, increasing public safety is an ambiguous goal which can be taken in many directions. All 36 counties offered an account for how they considered public safety when developing their JRI programs. The approaches for holding offenders accountable overlapped with the tactics of increase public safety. Offenders placed under supervision or in rehabilitative programs inherently makes the community a safer place.

Evidence-based community correction programs were developed in counties with the idea of successfully reducing recidivism. Counties claimed their community corrections programs did reduce recidivism as well as crime rates, which helped increase public safety. Counties that included substance abuse treatment and mental health counseling also claimed these services helped change offender behavior through successful reintegration. Some counties, such as Polk county, used increased law enforcement, while other counties found increased community supervision and collaboration with different agencies to be essential in increasing public safety. Much like the goal of offender accountability, counties resorted to both the listed long-term efforts for public safety and the use swift and certain sanctions as short-term public safety measures. Crook county provided two explanation about the efforts of increasing public safety. One explanation is more established claiming its Batterer's Intervention Program holds offenders accountable and increases public safety,

...the more offenders are engaged in treatment, whether it is inpatient or a structured outpatient program, or treatment in the jail facility, the less likely they are to reoffend. The more we can help offenders build their self-esteem, self- 
worth, change their life-style, stabilize them in housing and employment, the less likely they are to reoffend or victimize citizens in our community...Starting up a new Batterer's Intervention Program is a big step in public safety. If we can effect change in assaultive type behavior, then we can reduce the chances of more victims in our community. (Crook county application).

The other explanation relies on the size and involvement of the community,

Being in a small community, both our Department and the offenders are very much in the eye of the public. The Crook County Sheriff's Office also holds a Citizen Academy yearly and the public can be educated on what we do, what is expected of our offender population, and also learn judicial limitations.

The public is aware when offenders are incarcerated; they notice when they are out on the work crew, and they have a sense of security when there is visibility. (Crook county application).

The Crook county approach to increasing public safety has two very different methods. They recognize that their small community allows for more transparency, but they are still developing additional programs to actively work on reducing victims of domestic violence.

This section discussed how these counites have met the seven goals of the Justice Reinvestment Act. Table 6 displays which counties have stated they are meeting the goals of JRI. Table 6 also displays which goals are more commonly met in the state of Oregon. Focusing prison resources on violent offenders, investing in evidence-based community corrections, local law enforcement, specialty courts, and victim services were more established goals. There was a pool of options counties could have chosen for these goals, depending on their individual needs, whereas holding offenders accountable and 
Table 6

Seven goals of H. B. 3194 accounted for by each county

\begin{tabular}{|c|c|c|c|c|c|c|c|}
\hline & $\begin{array}{c}\text { Violent } \\
\text { Offences }\end{array}$ & $\mathrm{CC}^{*}$ & $\begin{array}{c}\text { Local } \\
\text { Agencies }\end{array}$ & $\begin{array}{l}\text { Specialty } \\
\text { Courts }\end{array}$ & $\begin{array}{l}\text { Victim } \\
\text { Service }\end{array}$ & $\begin{array}{l}\text { Account- } \\
\text { ability }\end{array}$ & $\begin{array}{l}\text { Public } \\
\text { Safety }\end{array}$ \\
\hline Multnomah & $\checkmark$ & $\checkmark$ & $\checkmark$ & $\checkmark$ & $\checkmark$ & $\checkmark$ & $\checkmark$ \\
\hline Washington & & $\checkmark$ & $\checkmark$ & & $\checkmark$ & $\checkmark$ & $\checkmark$ \\
\hline Clackamas & & $\checkmark$ & $\checkmark$ & $\checkmark$ & $\checkmark$ & $\checkmark$ & $\checkmark$ \\
\hline Lane & $\checkmark$ & $\checkmark$ & $\checkmark$ & $\checkmark$ & $\checkmark$ & $\checkmark$ & $\checkmark$ \\
\hline Marion & & $\checkmark$ & $\checkmark$ & $\checkmark$ & $\checkmark$ & $\checkmark$ & $\checkmark$ \\
\hline Jackson & $\checkmark$ & $\checkmark$ & & & $\checkmark$ & $\checkmark$ & $\checkmark$ \\
\hline Deschutes & & & $\checkmark$ & & $\checkmark$ & $\checkmark$ & $\checkmark$ \\
\hline Linn & & $\checkmark$ & & $\checkmark$ & $\checkmark$ & $\checkmark$ & $\checkmark$ \\
\hline Douglas & & $\checkmark$ & $\checkmark$ & $\checkmark$ & $\checkmark$ & $\checkmark$ & $\checkmark$ \\
\hline Yamhill & $\checkmark$ & $\checkmark$ & $\checkmark$ & & $\checkmark$ & $\checkmark$ & $\checkmark$ \\
\hline Benton & $\checkmark$ & $\checkmark$ & $\checkmark$ & $\checkmark$ & $\checkmark$ & $\checkmark$ & $\checkmark$ \\
\hline Josephine & & $\checkmark$ & $\checkmark$ & $\checkmark$ & $\checkmark$ & $\checkmark$ & $\checkmark$ \\
\hline Polk & & $\checkmark$ & $\checkmark$ & $\checkmark$ & $\checkmark$ & $\checkmark$ & $\checkmark$ \\
\hline Umatilla & & $\checkmark$ & $\checkmark$ & $\checkmark$ & $\checkmark$ & $\checkmark$ & $\checkmark$ \\
\hline Klamath & & & $\checkmark$ & $\checkmark$ & $\checkmark$ & $\checkmark$ & $\checkmark$ \\
\hline Coos & & $\checkmark$ & $\checkmark$ & & $\checkmark$ & $\checkmark$ & $\checkmark$ \\
\hline Columbia & & & $\checkmark$ & & $\checkmark$ & $\checkmark$ & $\checkmark$ \\
\hline Lincoln & & $\checkmark$ & $\checkmark$ & $\checkmark$ & $\checkmark$ & $\checkmark$ & $\checkmark$ \\
\hline Clatsop & $\checkmark$ & & $\checkmark$ & & $\checkmark$ & $\checkmark$ & $\checkmark$ \\
\hline Malheur & $\checkmark$ & $\checkmark$ & $\checkmark$ & $\checkmark$ & $\checkmark$ & $\checkmark$ & $\checkmark$ \\
\hline Tillamook & & $\checkmark$ & $\checkmark$ & & $\checkmark$ & $\checkmark$ & $\checkmark$ \\
\hline Wasco & & $\checkmark$ & & $\checkmark$ & $\checkmark$ & $\checkmark$ & $\checkmark$ \\
\hline Union & & $\checkmark$ & & & $\checkmark$ & $\checkmark$ & $\checkmark$ \\
\hline Jefferson & & $\checkmark$ & $\checkmark$ & $\checkmark$ & $\checkmark$ & $\checkmark$ & $\checkmark$ \\
\hline Crook & & $\checkmark$ & $\checkmark$ & $\checkmark$ & $\checkmark$ & $\checkmark$ & $\checkmark$ \\
\hline Hood River & & $\checkmark$ & & & $\checkmark$ & $\checkmark$ & $\checkmark$ \\
\hline Curry & & $\checkmark$ & & & $\checkmark$ & $\checkmark$ & $\checkmark$ \\
\hline Baker & & $\checkmark$ & & & $\checkmark$ & $\checkmark$ & $\checkmark$ \\
\hline Morrow & & & $\checkmark$ & & $\checkmark$ & $\checkmark$ & $\checkmark$ \\
\hline Lake & & & $\checkmark$ & $\checkmark$ & $\checkmark$ & $\checkmark$ & $\checkmark$ \\
\hline Harney & & $\checkmark$ & & $\checkmark$ & $\checkmark$ & $\checkmark$ & $\checkmark$ \\
\hline Grant & & $\checkmark$ & $\checkmark$ & & $\checkmark$ & $\checkmark$ & $\checkmark$ \\
\hline Wallowa & & $\checkmark$ & & $\checkmark$ & $\checkmark$ & $\checkmark$ & $\checkmark$ \\
\hline Gilliam & & & $\checkmark$ & & $\checkmark$ & & $\checkmark$ \\
\hline Sherman & & $\checkmark$ & & & $\checkmark$ & $\checkmark$ & $\checkmark$ \\
\hline Wheeler & & & $\checkmark$ & & $\checkmark$ & $\checkmark$ & $\checkmark$ \\
\hline
\end{tabular}

*Community Corrections 
increasing public safety were ambiguous goals. Counties likely had a broad interpretation on how to achieve these goals and responses likely required some creativity.

As stated above, every county was required to use ten percent of their funds towards victim services, thus $100 \%$ of counties met this goal. All 36 counties also stated their JRI programs increased public safety. Thirty-five of the 36 counties (97\%) included language to specify how they are holding offenders accountable for their actions while still aiming to decrease prison use. Only seven of the 36 counties (19\%) specified that they reserved prison resources for violent offenders and placed non-violent offenders in their community corrections programming. Evidence-based community correction programs were said to be implemented in 26 counites (72\%). Investing in local law enforcement was also claimed by $72 \%$ of counties. Nineteen counties (53\%) stated they invested in at least one specialty court. The more populated counties reached more goals than the less populated counties. Urban counties receiving more grant funds could account for their ability to reach more goals than rural counties.

The second research question aimed to explore the differences in programs across Oregon counties. The 2017-2019 grant applications revealed the intent to implement 95 JRI programs across Oregon. In addition, 56 victim service programs were proposed as required by the Oregon JRI grant program. For the purpose of this paper, victim service programs are discussed separately from the other JRI programs. The 95 JRI programs were divided into seven categorize: specialty courts, pre-trial programs, in-jail treatment services, community-based treatment centers, community corrections, additional staff and resources, and evidence-based assessment programs. Table 7 portrays the type(s) of 
Table 7

JRI program categories by county

\begin{tabular}{|c|c|c|c|c|c|c|c|}
\hline & $\begin{array}{c}\text { Specialty } \\
\text { Courts }\end{array}$ & $\begin{array}{l}\text { Pretrial } \\
\text { Program }\end{array}$ & $\begin{array}{c}\text { In-jail } \\
\text { Tx }\end{array}$ & $\begin{array}{c}\text { Comm. } \\
\text { Tx }\end{array}$ & $\mathrm{CC}^{*}$ & $\begin{array}{l}\text { Assess. } \\
\text { Centers }\end{array}$ & $\begin{array}{c}\text { Add. } \\
\text { Resources }\end{array}$ \\
\hline \multicolumn{8}{|l|}{ Multnomah } \\
\hline Washington & & & $\checkmark$ & & $\checkmark$ & & \\
\hline Clackamas & & $\checkmark$ & & $\checkmark$ & $\checkmark$ & & $\checkmark$ \\
\hline Lane & & & & & $\checkmark$ & & \\
\hline Marion & $\checkmark$ & & & $\checkmark$ & $\checkmark$ & & \\
\hline Jackson & & & & $\checkmark$ & $\checkmark$ & $\checkmark$ & \\
\hline \multicolumn{8}{|l|}{ Deschutes } \\
\hline Linn & & & $\checkmark$ & & $\checkmark$ & & \\
\hline Douglas & & & $\checkmark$ & & & & $\checkmark$ \\
\hline Yamhill & & $\checkmark$ & & & & $\checkmark$ & \\
\hline Benton & $\checkmark$ & & & & $\checkmark$ & & \\
\hline Josephine & & $\checkmark$ & $\checkmark$ & & & & $\checkmark$ \\
\hline Polk & $\checkmark$ & & & & $\checkmark$ & & $\checkmark$ \\
\hline Umatilla & & & $\checkmark$ & & $\checkmark$ & & $\checkmark$ \\
\hline Klamath & & & & & & & $\checkmark$ \\
\hline Coos & & & & & $\checkmark$ & & \\
\hline \multicolumn{8}{|l|}{ Columbia } \\
\hline Lincoln & & & & & $\checkmark$ & & \\
\hline Clatsop & & $\checkmark$ & & & & & \\
\hline Malheur & & & & & $\checkmark$ & & \\
\hline Tillamook & & & & & $\checkmark$ & & $\checkmark$ \\
\hline Wasco & $\checkmark$ & & & & $\checkmark$ & & \\
\hline Union & & & & & $\checkmark$ & $\checkmark$ & \\
\hline Jefferson & & & $\checkmark$ & & $\checkmark$ & & $\checkmark$ \\
\hline Crook & & & & $\checkmark$ & $\checkmark$ & & $\checkmark$ \\
\hline Hood River & & & & & $\checkmark$ & & $\checkmark$ \\
\hline Curry & & & & & $\checkmark$ & & \\
\hline Baker & & & & $\checkmark$ & $\checkmark$ & & \\
\hline Morrow & & & & & & & $\checkmark$ \\
\hline Lake & $\checkmark$ & & & & & & \\
\hline Harney & & & & & $\checkmark$ & & $\checkmark$ \\
\hline Grant & & & & & $\checkmark$ & & $\checkmark$ \\
\hline Wallowa & & & & $\checkmark$ & $\checkmark$ & & $\checkmark$ \\
\hline Gilliam & & & & $\checkmark$ & & & \\
\hline Sherman & & & & & $\checkmark$ & & $\checkmark$ \\
\hline Wheeler & & & & & & & $\checkmark$ \\
\hline
\end{tabular}

Note: Comm.=community, Tx=treatment, Assess.=assessment, Add.=additional

*Community Corrections 
program(s) each county had the intent of developing. Multnomah county, Columbia County, and Deschutes county all proposed one JRI program that consisted of different elements. These three programs were excluded from Table 7, as these programs were more encompassing and not dedicated to a single element of JRI. As well, Table 7 is not reflective of the number of intended programs in each county as some counties listed multiple programs under the same category.

Community corrections, additional staff and resources, and community-based treatment services were the most common type of programs. Community corrections was the most common with 24 counties aiming to implement specific programs tailored towards community corrections. Sixteen counties proposed programs with the purpose of hiring additional staff or resources, and seven counties wanted to create specific community-based treatment services. Specialty courts, evidence-based assessment centers, pretrial programs, and in-jail treatment services were the least common categories. Of the six counties that planned to implement in-jail treatment services, five were urban counties. Of the four counties that developed pretrial programs, only one was a rural county. These were the only differences observed between urban and rural counties. Most programs were dispersed evenly across Oregon.

Note that many counties already planned to incorporate treatment services in their community correction programs, thus not requiring the need to develop a specific program solely devoted to treatment. For example, Lincoln county planned to implement a community corrections program that also included community treatment services. Since the main program was community corrections, it was only recorded as such and not both 
community corrections and community treatment. Some counties planned to invest in existing programs like specialty courts, but they did not develop a specific program dedicated to specialty courts. These investment types were also excluded from Table 7.

So far, the discussion has focused on whether each county has implemented programs that fall in line with the Justice Reinvestment Act in Oregon. The third question remains whether the Justice Reinvestment Act is adhering to the spirit of the JRI literature. Whether or not Oregon has accomplished the goals of JRI is beyond the scope of this study. What is within the abilities of this research is whether Oregon has approached JRI in a manner that is in line with the literature. The Justice Reinvestment Act aims to invest in services known to reduce recidivism, reduce prison use for nonviolent offenders, increase public safety, and reinvest averted prison costs into local public safety infrastructure. While these goals fall in line with some of the literature surrounding JRI, there is missing language specifically related to proactive measures of ensuring successful reentry. Tucker and Cadora (2003) stress the need for JRI to invest in local programs that will create an environment suitable for successful reintegration such as healthcare, job availability, and educational opportunities. In other words, these programs should invest in the environment of offenders just as much as offenders themselves. Oregon's JRI bill does not address how to strengthen individual neighborhoods to keep residents out of prison.

According to Rivers (2011), JRI implementation requires four steps: 1) identify the causes of jails and prison population growth; 2) creating policies which generate savings and increase public safety; 3) quantify said savings and reinvesting in high-risk 
communities; and 4) measure the impact of these initiatives. Oregon has identified the drivers of prison and jail and developed several policies including removing mandatory minimums for repeat drug offenders and reducing sentences for marijuana offenses, driving while suspended, and other offences; and strengthening reentry programming by expanding transitional leave, implementing earned discharge, and requiring the use of risk-needs evaluations (LaVigne et al., 2014). Oregon is measuring the impact of these initiatives by requiring reporting progress and financial spending for community supervision, rehabilitation research, and evidence-based programing to the Oregon Criminal Justice Commission (CJC, 2018). According to the Urban Institute (2017) Oregon has reinvested $\$ 98$ million from upfront investment and subsequent reinvestment from savings and averted costs from 2013 to 2016.

Table 8 provides an overview of the goals of the justice reinvestment literature and whether these goals are stated in the Justice Reinvestment Act in Oregon. Oregon did include language in House Bill 3194 which states its aim to reduce prison use, reduce recidivism, reduce prison costs, and maintain public safety. LaVigne et al. (2014) and House Bill 3194 show Oregon worked to identify the drivers of mass incarceration and create policy which targeted certain offenses. It also emphasizes the goal of reinvesting actual savings after they are realized. The two goals that Oregon does not mention are the need to invest proactive measures which will keep people out of prison and the need to focus reinvestment on high risk communities. 


\section{Table 8}

Justice reinvestment goals included in Oregon's Justice Reinvestment Act Goals of General JRI Justice Reinvestment Act

Identify driver of incarceration Included

Create policy to address drivers Included

Decrease prison use Included

Reduce recidivism Included

Reduce prison costs Included

Maintain public safety Included

Reinvest actual savings Included

Assess measures Included

Invest in proactive measures

Not included

Reinvest in the physical infrastructure Not included 


\section{Discussion}

The language in the 2017-2019 JRI grant applications was tailored towards reducing recidivism through the use of community corrections and treatment services. The application itself was focused on questioning how counties planned to reduce recidivism and consequently, counties focused on explaining their plans on recidivism. The claims associated with public safety and offender accountability were strongly associated with community correction services and the reduction of recidivism. Counties were certain their community correction programs were successfully reducing recidivism and crime. They believed these achievements would effectively increase public safety. Their justification for holding offenders accountable was by placing them into alternative sanctions for their actions.

While specialty courts are also an evidence-based practice used to reduce recidivism, only 19 counties alleged to invest in these types of courts. Specialty courts work to address the underlying issues that impact criminal behavior with the goal of diverting offenders away from prison or jail and provide rehabilitative services to reduce recidivism (Wood et al., 2018). Drug courts were the most common type of courts across the grant application. This is not surprising given it is the most well-known specialty court in the nations (Morgan et al., 2016). This analysis cannot conclude whether counties that have not invested in specialty courts do not have access to these services. It could be that the county is already funding these courts and there is no need for additional funds. They could be putting their JRI funds towards more eminent matters. Counties that do not have access to specialty courts should consider partnering with neighboring 
counties with these services. They could work together by sharing judges and information to provide defendants with appropriate services, including treatment and sanctions. This collaboration would benefit the individual, the public, and the state by steering them away from incarceration and providing rehabilitative services. This collaboration would fall in line with the JRI notion of centering the responsibility on the government, community, and the individual.

Oregon is one of only eight JRI states to invest in victim services and the only state that requires a specified percentage of their JRI funds to go towards victim services (Welsh-Loveman \& Harvell, 2018). Victim services are generally not discussed within the broader JRI literature, setting Oregon apart. There were three overarching categories for victim services in Oregon: domestic violence and sexual assault, child abuse and neglect, and general victim services. Domestic violence and sexual assault services were the most common, with 30 counties (83\%) aiming to fund these programs. The high number of investments in these programs could mean there is high demand for victim services related to domestic violence and sexual assault. The specific content of each program seemed to be focused on women, utilizing women's shelters and like services. One in seven men are victims of domestic violence (Niolon et al., 2017), but there was no language in the 2017-2019 applications to suggest programs are being developed to assist male victims of domestic violence and sexual assault. Again, the grant application coordinators should take note of this lack of service.

Oregon is only one of three JRI states to invest in local law enforcement (WelshLoveman \& Harvell, 2018). In Oregon, urban counites were found more likely to invest 
in additional officers, while rural counites were more likely to invest in officer training and equipment. In general, urban counties received more funds than rural counties given they have more residents to service. More populated counties likely had the funds and the justifications to hire more personnel, whereas rural counties might benefit more from training the officers they already have and investing in company equipment.

It is not clear whether rural counties received less funds because they need less or because the state cannot justify giving these counties more money. The Justice Reinvestment Act gives counties the flexibility to implement programs that best fit their needs, however, if smaller counties are not being given the necessary resources then they will be limited on the type of programs they can develop. The current analysis does not provide proof for these claims, but nonetheless, the CJC should take these thoughts into consideration when distributing the grant funds.

Table 9 provides an overview of how Oregon counties are doing in regards to the goals of the Justice Reinvestment Act. Most counites are wanting to invest in community corrections, law enforcement, specialty courts, and victim services. Only a little over half the counties plan to invest in specialty courts, which means there needs to be a bigger effort on behalf of the other counties. Almost every county gave an account as to how they are promoting offender accountability and public safety. Focusing prison resources on violent offenders is the only goals where counites are lacking language. Only $19 \%$ of county applications specifically describe how they are meeting this goal. However, Oregon did amend its laws to reduce sentences for some non-violent offenses. The CJC should ensure counties are using their JRI for non-violent offenders. 


\section{Table 9}

Seven goals of H. B. 3194 summary

\begin{tabular}{ll}
\hline House Bill 3194 Goals & Met/partially met \\
\hline 1) Focus prison resources on violent offenders & Partially met \\
2) Invest in evidence-based community corrections & Met \\
3) Invest in local law enforcement & Met \\
4) Invest in specialty courts & Partially met \\
5) Invest in victim services & Met \\
6) Hold offenders accountable & Met \\
7) Increase public safety & Met \\
\hline
\end{tabular}

The grant application for JRI funds in Oregon lacks specific language related to the goals of House Bill 3194. The application describes the bill as having four goals: 1) reduce recidivism through evidence-based practices, 2) reduce prison populations for property, drug, and driving offenses, 3) increase public safety, and 4) hold offenders accountable. They also include investing in victim services as another goal in a different section of the application. House Bill 3194 clearly states the need to focus prison resources on violent offenders, invest in community corrections, specialty courts, and law enforcement, and it requires reinvesting in local public safety infrastructure and yet this text is not included in the grant application.

The first goal listed in the application seems to be an overarching goal for investing in community corrections, specialty courts, and law enforcement as these are all 
vital in reducing recidivism. Since the goal of the Justice Reinvestment Act is to give counties the liberty to implement the programs that best fit their local needs, this general language may give counties that flexibility. It seems unrealistic for counites, especially smaller counties, to invest in all the listed programs. This does not change the fact that the goals of the Justice Reinvestment Act are to invest in all these services. The findings suggest counties are not given enough guidelines for where they need to be investing. The application needs to include a list of these programs and require counties to invest in at least one type of service in an effort to increase the success of JRI in Oregon.

The second goal in the application hints at the need to focus prison resources on violent offenders and reduce prison use for non-violent offenders. This language in this section needs to be tightened so counties are clear about excluding violent offenders from their community based JRI programs. The target population is required for every program listed in the application. This section of the application needs to ask if violent offenders will be eligible for the program. This tighter language will hold more counties accountable on meeting the first goal of the Justice Reinvestment Act.

Developing an application with specific language on the goals of the Justice Reinvestment Act will give counties a better understanding of the bill. If counties do not have a clear understanding of the JRI literature or even the Oregon bill itself, then trying to create programs that fall in line with the goals will be a difficult task. Having an application with specific language about the requirements of the bill could provide counties with more resources to understand the point of JRI and subsequently lead to better program development. 
States with JRI have invested almost three dollars out of every five dollars into community supervision and community-based treatment and services, which is roughly 57\% of total JRI reinvestment (Welsh-Loveman \& Harvell, 2018). Community corrections was the most common type of program implemented across Oregon as seen in Table 7. These programs ranged from reentry, transitional housing, diversion, day reporting, work crew, and general services. Reentry and transitional housing were the most common forms of community corrections. The majority of community correction programs included a treatment aspect. Taxman et al. (2014) stress the importance of including and increasing the number of accessible intervention and treatment programs in JRI efforts. They call for effective programing both within correctional and community settings. They argue that increased access to these programs can reduce recidivism rates as well as reincarceration rates. The 2017-2019 grant applications demonstrate Oregon's commitment to these programs. There is a clear need for more treatment services within correctional facilities as only two counties planned to develop specific programs for these services. The grant program coordinators should take note of this lack of service. They could either work with counties to implement more services or they could directly invest in them at the state level.

The Justice Reinvestment Act does follow the justice reinvestment literature for the most part. Table 1 and Table 8 demonstrate the goals of JRI in Oregon are very similar to those of the general JRI literature. There are two goals not being planned by Oregon, which include taking proactive measures to create a better environment upon 
offender release and focus reinvestment in communities most impacted by mass incarceration.

\section{Policy Recommendations}

The Justice Reinvestment Act should be amended to include the full extent of the JRI literature. The amendment should include a plan or goal of reinvesting in the environment of communities with high imprisonment rates. It should include a plan for strengthening neighborhoods to keep residents away from prison. More targeted community-specific investments, as opposed to system-wide investments, is the component of Oregon's JRI goals and initiatives that is most lacking when contrasted with earlier visions of JRI described by Tucker and Cadora (2003) and Clear (2011). The amendment should include a separate fund solely focused on creating proactive measures in high risk communities. This fund should not follow the same structure as the grant application. Rather, the state of Oregon needs to identify the neighborhoods with the highest rates of imprisonment and directly work with the county in developing the best programs for that neighborhood. Depending on the needs of the neighborhood a number of programs can be created such as investing in public schools and structured activity for youth to deter delinquency. A scholarship fund could be started in low-income neighborhoods with underprivileged schools. If the issue of high imprisonment in a neighborhood stems from high single-parent households, then vocational training and affordable childcare centers can be developed. If unemployment is a major concern, then the county could form partnerships with local communities to create jobs. They could even hire those returning to the community to rebuild the physical infrastructure of the 
neighborhood. This would benefit the community and teach the offender vocational skills. These should not be confused with work crew programs or restitution jobs. Rather these should be formal jobs where the offender can also give back to the community by building aspects of the community. The number of possible programs is extensive, but the county and state should clearly identity the underlying issue leading to high rates of imprisonment and develop programs accordingly.

An agency level policy can also be provided given the literature. Agencies should adapt a geographic approach for assigning cases to parole and probation officers. Parole and probations officers should be assigned cases based on the neighborhood of the offenders rather than being dispersed through the city or county. Focusing on a single neighborhood allows officers to better understand the needs of that community which would improve the productivity of the officer and improve the level of support they provide their clients.

\section{Limitations}

The data for this research is from the 2017-2019 biennial grant cycle. There have been two rounds of grant applications before this cycle and one currently underway. Only studying one round of grant distributions narrows the scope of the type and quantity of programs developed across Oregon. The narrow scope has the potential to distort the perception of what is being implemented across Oregon. For example, additional equipment for all counties could have been bought with the 2013-2015 grant awards and thus not present in the 2017-2019 applications. Future research needs to examine the application since the 2013-2015 biennial until the most current application cycle to get a 
broader picture of JRI programs in Oregon. This study should be replicated after 2023, when the CJC estimates the effects of JRI will be more evident (LaVigne et al., 2014).

Another limitation of this study is the uncertainty of the applications. This data cannot determine if these programs were actually developed in each county. The data can only display the intention and the area of focus for each county. This analysis found most counties did account for how they are holding offenders accountable and increasing public safety. This does not mean they are actually following through with their claims. On the other hand, just because counties did not explicitly state they are focusing prison resources on violent offenders does not mean are not meeting this goal. Verifying whether these goals were being met was out of the scope of this research.

The vagueness of certain goals allowed for a broad interpretation on behalf of the counties. This hinders the reliability of the findings because the interpretation is too broad for a comparison across counties. 


\section{Conclusion}

The stated goals of the 36 counties in Oregon fall in line with the majority of goals in the Justice Reinvestment Act. The structure of the grant application plays a role in only $19 \%$ of counties stating they plan to exclude violent offenders from their JRI programs. If the question were explicitly stated in the application as to their inclusion or exclusion of violent offenders, counties could better express their methods for reaching these objectives. The grant program needs to edit the application to include sharper language related to violent offenders.

After reviewing the literature on JRI and House Bill 3194 it became evident that the Justice Reinvestment Act is falling a bit short on the intended purpose of JRI as described by some of its founding proponents. It is recommended that House Bill 3194 is amended to reflect the full literature of JRI. As it stands, the act is more reflective of a bill designed to reduce recidivism by focusing exclusively on criminal justice system investments. The amendment should include an additional grant to invest in neighborhoods with high imprisonments rates. The state needs to identify these neighborhoods and work directly with the county to identify proactive measures. These measures should strengthen the neighborhood resources, infrastructure, and networks to prevent prison admissions and successfully reintegrate returning inmates. Investing in the environment of these communities is a vital step in the JRI literature. 


\section{References}

Alexander, M. (2012). The new Jim Crow: Mass incarceration in the age of colorblindness (revised ed.). The New Press.

Alper, M., Durose, M. R., Markman, J. (2018). 2018 update on prisoner recidivism: A 9year follow-up period (2005-2014). Bureau of Justice Statistics. https://www.bjs.gov/index.cfm?ty=pbdetail\&iid=6266

Bernard, T. J., Snipes J. B., \& Gerould, A. L. (2016). Vold's theoretical criminology (7th ed.). Oxford University Press.

Bureau of Justice Statistics (BJS). (1982). Prisoners 1925-81. https://www.bjs.gov/index.cfm?ty=pbdetail\&iid=3414

Bureau of Justice Statistics (BJS). (1984). The 1983 jail census. https://www.bjs.gov/index.cfm?ty=pbdetail\&iid=4016

Carson, E. A. (2020). Prisoners in 2018. Bureau of Justice Statistics. https://www.bjs.gov/index.cfm?ty=pbdetail\&iid $=6846$

Clear, T. R. (2011). A private-sector, incentives-based model for justice reinvestment. Criminology \& Public Policy, 10(3), 585-608. https://doi-org.proxy.lib.pdx.edu/10.1111/j.1745-9133.2011.00729.x

Clear, T. R. \& Frost, N. A. (2014). Punishment imperative: The rise and failure of mass incarceration in America. New York University Press.

Council of State Governance (CSG) Justice Center. (n.d.). Justice reinvestment: Reinvest in what works. https://csgjusticecenter.org/projects/justice-reinvestment/

Craddock, A. (2004). Estimating criminal justice system costs and cost-savings benefits of day reporting centers. Journal of Offender Rehabilitation, 39(4), 69-98. https://doi-org.proxy.lib.pdx.edu/10.1300/J076v39n04 05

Cullen, F.T., Agnew, R., \& Wilcox, P. (2018). Criminological theory: Past to present: Essential readings ( $6^{\text {th }}$ ed.). Oxford University Press.

Ditton, P. M. \& Wilson D. J. (1999). Truth in sentencing in state prisons. Bureau of Justice Statistics. https://www.bjs.gov/index.cfm?ty=pbdetail\&iid=820

Drisko, J. W., \& Maschi, T. (2015). Content analysis: Pocket guides to social work research methods. Oxford University Press.

Federal Bureau of Investigation (FBI). (n.d.). Uniform Crime Reporting Statistics. https://www.bjs.gov/ucrdata/Search/Crime/State/RunCrimeStatebyState.cfm

Forman, J. (2017). Locking up our own: Crime and punishment in Black America. Farrar, Straus and Giroux.

Frailing, K. (2010). How mental health courts function: Outcomes and observations. International Journal of Law and Psychiatry, 33(4), 207-213. https://doi-org.proxy.lib.pdx.edu/10.1016/j.ijlp.2010.06.001

Garland, B., Wodahl, E., \& Saxon, C. (2017). What influences public support of transitional housing facilities for offenders during reentry? Criminal Justice Policy Review, 28(1), 18-40. https://doi-org.proxy.lib.pdx.edu/10.1177\%2F0887403414564866

Gill, C., \& Wilson, D. B. (2017). Improving the success of reentry programs: Identifying 
the impact of service-need fit on recidivism. Criminal Justice and Behavior, 44(3), 336-359. https://doi-org.proxy.lib.pdx.edu/10.1177\%2F0093854816682048

House Bill 3194. 77 $7^{\text {th }}$ Assembly, 2013 Regular Session (OR, 2013).

Kaeble. D. \& Cowhig, M. (2018). Correctional populations in the United States, 2016. Bureau of Justice Statistics. https://www.bjs.gov/index.cfm?ty=pbdetail\&iid=6226

LaVigne, N., Bieler, S., Cramer, L., Ho, H., Kotonias, C., Mayer, D., McClure, D., Pacifici, L., Parks, E., Peterson, B., \& Samuels, J. (2014). Justice Reinvestment Initiative state assessment report. Urban Institute. https://www.urban.org/research/publication/justice-reinvestment-initiative-stateassessment-report

Marvell, T. B., \& Moody, C. E. (1996). Determinate sentencing and abolishing parole: The long-term impacts on prisons and crime. Criminology, 34(1), 107-128. https://doi-org.proxy.lib.pdx.edu/10.1111/j.1745-9125.1996.tb01197.x

Miller, J., \& Maloney, C. (2013). Practitioner compliance with risk/needs assessment tools: A theoretical and empirical assessment. Criminal Justice and Behavior, 40(7), 716-736. https://doi-org.proxy.lib.pdx.edu/10.1177\%2F0093854812468883

Morgan, R. D., Mitchell, S. M., Thoen, M. A., Campion, K., Bolaños, A. D., Sustaíta, M. A., \& Henderson, S. (2016). Specialty courts: Who's in and are they working? Psychological Services, 13(3), 246-253. http://dx.doi.org.proxy.lib.pdx.edu/10.1037/ser0000085

Niolon, P. H., Kearns, M., Dills, J., Rambo, K., Irving, S., Armstead, T. L., \& Gilbert, L. (2017). Preventing intimate partner violence across the lifespan: A technical package of programs, policies, and practices. Centers for Disease Control and Prevention.

https://www.cdc.gov/violenceprevention/intimatepartnerviolence/fastfact.html

Oregon Criminal Justice Commission (CJC). (2018). Task Force on Public Safety: Preliminary report to the Oregon Legislature. https://digital.osl.state.or.us/islandora/object/osl:506534

Oregon Criminal Justice Commission (CJC). (n.d.a). Justice reinvestment: Information about the JRI grant and related programs. https://www.oregon.gov/cjc/jri/Pages/default.aspx

Oregon Criminal Justice Commission (CJC). (n.d.b). Justice reinvestment county programs: Statistical analysis center. https://www.oregon.gov/CJC/SAC/Pages/jri.aspx

Oregon Department of Corrections (DOC). (2018). Research and information request: Requesting information and doing research with DOC. https://www.oregon.gov/doc/about/Pages/prison-locations.aspx

PEW Charitable Trust (PEW). (2018). 35 states reform criminal justice policies through justice reinvestment: Legislative action aims to increase public safety return on corrections spending. https://www.pewtrusts.org/en/research-and-analysis/factsheets/2018/07/35-states-reform-criminal-justice-policies-through-justicereinvestment

Quesada, F. J. M. (2010). Concept mapping from qualitative interviews: A case of 
methodological integration using ATLAS/ti and SPSS. Papers, 95(2), 507-529. https://doi.org/10.5565/rev/papers/v95n2.43

Rivers, J. L. (2011) Improving criminal justice and reducing recidivism through justice reinvestment. Bureau of Justice Assistance.

https://bja.ojp.gov/library/publications/improving-criminal-justice-and-reducingrecidivism-through-justice

Roberts, J. V. (2003). Public opinion and mandatory sentencing: A review of international findings. Criminal Justice and Behavior, 30(4), 483-508. https://doi-org.proxy.lib.pdx.edu/10.1177\%2F0093854803253133

Salehijam. M. (2018). The value of systematic content analysis in legal research. Tilburg Law Review, 23(1), 34-42. https://doi.org/10.5334/tilr.5

Snell, T. L. (1995). Correctional populations in the United States, 1993. Bureau of Justice Statistics. https://www.bjs.gov/index.cfm?ty=pbdetail\&iid=746

Taxman, F. S., Pattavina, A., \& Caudy, M. (2014). Justice reinvestment in the United States: An empirical assessment of the potential impact of increased correctional programming on recidivism. Victims \& Offenders, 9(1), 50-75. https://doi-org.proxy.lib.pdx.edu/10.1080/15564886.2013.860934

Tucker, S. B., \& Cadora, E. (2003). Justice reinvestment: To invest in public safety by reallocating justice dollars to refinance education, housing, healthcare, and jobs. Open Society Institute, 3(3), 1-8.

https://www.opensocietyfoundations.org/publications/ideas-open-society-justicereinvestment

United States Census Bureau. (2019). 2010 census urban and rural classification and urban area criteria. https://www.census.gov/programssurveys/geography/guidance/geo-areas/urban-rural/2010-urban-rural.html

United States Census Bureau. (n.d). Annual estimates of the resident population: April 1, 2010 to July 1, 2018. http://www.census.gov/

Urban Institute. (2017). Justice Reinvestment Initiative state data tracker. http://apps.urban.org/features/justice-reinvestment/

Welsh-Loveman, J. \& Harvell. S. (2018). Justice Reinvestment Initiative data snapshot: Unpacking reinvestment. Urban Institute. https://www.urban.org/research/publication/justice-reinvestment-initiative-datasnapshot

West, H. C., Sabol, W. J. (2009). Prison inmates at midyear 2008 - statistical tables. Bureau of Justice Statistics. https://www.bjs.gov/index.cfm?ty=pbdetail\&iid=839

Wong, J. S., Bouchard, J., Lee, C., \& Gushue, K. (2019). Examining the effects of day reporting centers on recidivism: A meta-analysis. Journal of Offender Rehabilitation, 58(3), 240-260. https://doi-org.proxy.lib.pdx.edu/10.1080/10509674.2019.1583300

Wood, E. F., Miller, M. K., \& Kaplan, T. (2018). Specialty courts: Time for a thorough assessment. Mississippi College Law Review, 36(3), 332-349.

Wood, W. R. (2012). Correcting community service: From work crews to community work in a juvenile court. Justice Quarterly, 29(5), 684-711. https://doi-org.proxy.lib.pdx.edu/10.1080/07418825.2011.576688 
Wortley, R. \& Townsley, M. (2017). Environmental criminology and crime analysis $\left(2^{\text {nd }}\right.$ ed.). Routledge.

Zeng, Z. (2020). Jail inmates in 2018. Bureau of Justice Statistics. https://www.bjs.gov/index.cfm?ty=pbdetail\&iid=6826 